\title{
The Efficacy of Ethnic Stacking: Military Defection during Uprisings in Africa
}

\author{
Julien Morency-Laflamme, John Abbott College
}

Theodore McLauchlin, Université de Montréal

Journal of Global Security Studies 5, no. 4 (2020) : 695-702

\begin{abstract}
Does ethnic stacking in the armed forces help prevent military defection? Recent research, particularly in Africa and the Middle East, suggests so: by favoring ingroups, regimes can keep in-group soldiers loyal. In-group loyalty comes at the cost of antagonizing members of out-groups, but many regimes gladly run that risk. In this research note, we provide new large-scale evidence of the impact of ethnic stacking on the incidence of military defection during uprisings from below. Using data on fiftyseven popular uprisings in Africa since formal independence, we find clear support for the downsides of ethnic stacking: the practice is associated with more frequent defections if out-group members are still dominant in the armed forces. We find more limited support for the hypothesized payoff. Ethnic stacking may reduce the risk of defection, but only in regimes without a recent history of coup attempts. Future research should therefore trace the solidification of ethnic stacking over time.
\end{abstract}


During the Arab Spring, ruling regimes in Bahrain and Syria successfully avoided the wholesale change in military loyalties that took place in Egypt. As elsewhere in the world, military defections helped to decide the outcomes of these uprisings: weak uprisings can overcome strong regimes when security forces hold their fire or switch sides (Chorley 1943; Russell 1974; Chenoweth and Stephan 2011; Barany 2016). Bahrain and Syria may have taken a different course from Egypt because of the domination of sectarian minorities in the armed forces (Nepstad 2013; Makara 2013). Ethnic stacking, in theory, gives members of a preferred ethnic category a clear stake in the regime's continued survival that outweighs whatever benefits an opposition group can credibly offer. These officers may fear that, even if they defect, they and their friends and family will be associated with the incumbent and, therefore, vulnerable. Does ethnic stacking in armed forces actually work? In particular, does it help regimes keep their armies loyal in the face of uprisings from below?

To provide the first large- $\mathrm{N}$ answer to this question, this research note examines the relationship between ethnic stacking and defection in a set of all fifty-seven uprisings from below in Africa since independence identified by the NAVCO dataset (Chenoweth and Stephan 2011). We find, consistent with ethnic stacking theory, that ethnic stacking leads to more defections when the regime implements it in the face of a dominant group in the officer corps that it seeks to marginalize. This is the downside risk of ethnic stacking. However, we find only limited evidence for the supposed upside of ethnic stacking for a regime. Specifically, regimes that successfully put an ethnic in-group in a dominant position in the officer corps appear, overall, no less likely to experience defection than those that do not employ ethnic stacking at all. 
However, we do find potential evidence for a temporally bounded approach to ethnic stacking. Stacking appears to prevent defection provided a regime has not recently experienced a coup attempt. We suggest that this may be because it takes time for ethnic stacking to push expectations about behavior to converge along certain identity lines; in regimes with recent coup attempts, it is possible that this has not yet occurred. Regimes would thus have to survive a potential period of instability to reap the loyalty benefits of ethnic stacking.

\section{Ethnic stacking: theory and empirical expectations}

We define ethnic stacking as the practice of recruiting and promoting members of certain communal groups seen as more loyal, called in-groups, within the security forces; this favoritism harms communal groups seen as less loyal, called out-groups. Ethnic stacking therefore involves promoting groups seen as likely to be loyal to positions where loyalty matters most: senior officer positions (Singh 2014); command of military units that will be tasked with protecting the capital (De Bruin 2018); and internal security and intelligence. This policy limits out-group officers' careers and typically puts them under greater surveillance and suspicion (Bou Nassif 2015).

We term these ethnic stacking policies "incomplete" when only selected positions within the security forces are stacked with in-group members and a majority of officers come from out-groups. In contrast, ethnic stacking is "complete" when it overhauls the composition of the officer corps and in-group members come to represent a majority of officers. We elaborate this distinction below. 
The logic of ethnic stacking arises from the problem of military disloyalty. It examines in particular how identity intersects with the problem of knowing who is loyal and who is not. During coup attempts and uprisings from below, political leaders face a problem of information about the motivations of their security personnel (McLauchlin 2010); they are unsure who among them will be especially inclined to defect. Military personnel, after all, have good reason to hide their preferences. Notably, the decision of whether to support or oppose the regime, in both coups and uprisings, resembles a coordination game (Kuran 1991; Powell 2012; Singh 2014; Casper and Tyson 2014; Talmadge 2015; Sudduth 2017b). Officers seek to be on the winning side, for the sake both of one's own career (and life) and of preserving military unity. So they often hide their true preferences, going along with a winning side until another looks like it is likely to win.

However, these are not pure coordination games, in which all officers care about is being on the winning side. Different officers favor the victory of one side or another of a coup attempt or uprising, and thus vary widely in how likely it is that they will rebel (Kuran 1991; La Parra-Pérez 2014; Singh 2014, 63). Nevertheless, they still have strong reason to keep this true preference a secret and "go with the flow." In sum, officers vary in their preferences about the regime and may be more or less likely to join an effort to topple it, but it is hard to find out what their preferences are because of their fear of reprisals.

Hence a critical aspect of how regimes protect themselves is by assessing loyalties through internal surveillance and recent disloyal behavior. This helps them to determine who is likely to participate and to pre-empt (Brooks 1998; Quinlivan 1999; Sudduth 
2017a). De Bruin (2018) goes farther, arguing that divisions in the armed forces protect a regime above all by creating an interest in defending the regime. Notably, as de Bruin argues, leaders set up elite protection forces whose members will fear purges after successful coups and thus be especially inclined to oppose those coups. In sum, regimes have strong incentives to try to both detect disloyal preferences and to create them endogenously.

Both of these mechanisms underlie ethnic stacking, as McLauchlin (2010) theorizes. That is, identity works both as a source of information and a way of crystallizing competing interests. Leaders look to ethnic identity as a proxy for loyalties, based on an "ethnic security map" (Enloe 1980, 27) that suggests to a leader which groups are more loyal and which less. But at the same time, ethnic stacking policies create self-fulfilling prophecies. Ethnicity becomes an indicator of loyalties not just in the eyes of the political leader that puts ethnic stacking in place, but in the eyes of the public at large as well. It becomes easy to see any Alawite officer as a regime loyalist in Syria, for example. Alawite officers, in turn, fear that their identity marks them out as loyalists, to be purged after a successful coup plot or victorious uprising. In short, in-group officers fear that, however they act during a coup or uprising, they may be removed from their posts or killed. Officers who have been recruited and promoted due to their communal ties with leaders must "sink or swim" with the incumbent government (Bratton and van de Walle 1994, 464). They are thus in what McLauchlin (2018) calls a "loyalty trap": ingroup members are loyal to the regime in part because everyone expects them to be loyal, 
and so in-group members expect the opposition to discriminate against them (see also Chandra 2004, 2006; Chandra and Wilkinson 2008). ${ }^{1}$

The same logic applies to out-group members, albeit in reverse. Members of a marginalized group in the officer corps will know that their identity marks them out for suspicion and limits their career chances. Out-group members should thus be more motivated to defect under ethnic stacking, even as in-group members are less likely to. Hence, as we explore below, the net effect on overall defection should thus depend on the relative presence and position of in-group and out-group members-or, in other words, on how completely ethnic stacking is applied.

In short, ethnic stacking theory argues that while a regime may fear out-group disloyalty to begin with, and have more confidence in in-group members, the policy of ethnic stacking reinforces these tendencies by publicly associating group members with the regime. Stacking should have an exogenous impact on the propensity to defect, going beyond the initial distribution of loyalties along ethnic lines.

No study thus far conducts a large cross-national test of the stacking logic in the context of uprisings. Large- $\mathrm{N}$ analyses of coup attempts in Africa do find that these attempts are less likely in countries where the leader's group successfully dominates the officer corps (Harkness 2016) or the executive more generally (Roessler 2011).

In contrast to coups, we focus here on mass defection in the context of uprisings from below. But mass defection in this context above all occurs when the rank and file

\footnotetext{
${ }^{1}$ This analysis suggests that there is not much inherent to ethnicity that makes it work where other labels of loyalties, like class or membership in a particular elite military unit, would not; but it is a particularly widespread set of markers.
} 
switch sides. Therefore, one important question is whether there is a connection between stacking in the officer corps and ordinary soldiers' behavior. We believe there is. Commanding officers are in a position to push all their subordinates to defect with them by using their power to order them (Harkness 2016, 592; Albrecht and Ohl 2016, 45-47). More senior officers can use communication channels they regularly use and their military standing to lobby for their subordinates within multiple units to defect (Harkness 2016, 592; Singh 2014, 35-36). While the rank and file can still defect without officers, this is hard: officers often keep a close watch on their soldiers and ensure compliance, so ordinary soldiers must often wait for surveillance breakdowns before trying to defect (Koehler, Ohl, and Albrecht 2016, 47-48). Ethnic stacking in the officer corps thus should help the regime to prevent mass defection down the chain of command. Putting in-group officers in senior positions means that far fewer orders to defect are issued to subordinates. When junior in-group officers are ordered to defect, they are likely to refuse and to prevent such orders from being passed to their own subordinates. What seems to apply to officers in coups may also therefore apply to ordinary soldiers and uprisings from below.

Indeed, case study research from Africa and the Middle East seems to confirm this. Ethnic stacking has kept members of in-groups loyal in the face of some important uprisings from below, while possibly making out-group officers more inclined to defect (McLauchlin 2010; Makara 2013; Nepstad 2013; Bou Nassif 2015; Morency-Laflamme 2016; Koehler, Ohl, and Albrecht 2016; though on the Arab Spring, see also Koehler 2017). These findings about popular uprisings in comparative case-study research have yet to receive large-N confirmation. Do the findings travel and generalize? 
We should note that our empirical analysis encompasses both violent and nonviolent uprisings. Is this an appropriate scope condition? True, the (initially) nonviolent cases of the Arab-world uprisings of 2011 loom large in the ethnic stacking literature (Brooks 2019). However, existing analyses of defection patterns in Syria that consider the civil war period and find little differences between that time and the period of nonviolent uprising. If anything, the identity effect seems stronger in wartime (Bou Nassif 2015; Koehler, Ohl, and Albrecht 2016). Further, other cases that motivate stacking theory are violent; for example, McLauchlin (2010) includes two cases (Jordan, 1970; Iran, 1978-79) that some datasets (Fearon and Laitin 2003) consider violent enough to count as civil conflicts (Iran is debatable here; Jordan is not). Large-N analyses also find that ethnic exclusivity in access to executive power is associated with long civil wars as both sides, and notably the regime, harden with respect to identity shifts (Wucherpfennig et al. 2012; McLauchlin 2018). There are therefore good reasons to expect that the key hypotheses of ethnic stacking theory should apply to both. Still, we investigate the difference between violent and nonviolent contexts in a supplemental file and find little effect on the efficacy of stacking.

For this study, we derive broad hypotheses that focus on explaining the incidence of mass defection across the whole army. This overall portrait of defection-rather than the behavior of members of particular groups-matters for the outcomes of uprisings (Russell 1974; Chenoweth and Stephan 2011). Hence, analyzing whether mass defection occurs gives a good first cut at a politically important phenomenon.

The net effect of ethnic stacking on the overall rate of defection depends on how far the stacking policy goes. Out-group members may still have quite a large presence, 
and the seniority to be able to defect with large numbers of subordinates. This was the case in Benin, where only senior positions and the presidential guard were stacked with Northerners; southerners, particularly Fons, still represent more than half of the officer corps (Allen 1992, 44). A leader may be in the process of promoting his allies and purging his adversaries, but this takes time and care since out-group members are losing their position and have incentives to resist, including by launching a coup or rebelling before they are too weak to do so (Sudduth 2017a, 2017b). During this process, as long as out-group members still outnumber in-group members in the officer corps (we call this “incomplete ethnic stacking”), rebellions from below pose considerable dangers for a regime. Out-group officers may take advantage of rebellions from below to defect.

In contrast, a leader employing ethnic stacking could essentially eliminate the downside disloyalty risk when in-group officers dominate the officer corps numerically (“complete ethnic stacking”). In Zaire/DRC, for instance, President Mobutu almost completely stacked the officer corps with officers from his native Equateur region; officers from this group represented close to 80 percent of the officer corps by the end of Mobutu's rule (Emizet 2000, 216). Out-group members might form only a small share of an army, or only in subordinate and easily controlled positions. They may therefore have little opportunity to defect, and their defection may not move the overall rate much. This key distinction therefore leads to two separate hypotheses:

H1. Incomplete ethnic stacking should be associated with a higher incidence of defection, relative to contexts characterized by either (a) a lack of stacking or (b) complete ethnic stacking. 
H2. Complete ethnic stacking should be associated with a lower incidence of defection, relative to conditions that lack ethnic stacking.

It is possible that other variables could influence how stacking affects defection. Violent uprisings by challengers who explicitly mobilize out-group grievances might be especially likely to prompt in-group members to stick with the regime out of fear. Alternatively, it may be that they rally regardless of how the opposition behaves because they regard opposition claims to pluralism and nonviolence as not credible (McLauchlin 2018). While we are not able to analyze the impact of ethnic claims for this research note because of data limitations, we do analyze the impact of violent rebellions and find little change in our results. The complete analysis is available in a supplemental file.

\section{Empirical analysis}

In this research note, we study the impact of ethnic stacking on defection in fiftyseven NAVCO uprisings in Africa since political independence (or since 1945, in the cases of Liberia and Ethiopia). In doing so, we study a region where ethnic stacking theory has received support in case-study research (Morency-Laflamme 2018) and where consonant hypotheses for coups have found support (Roessler 2011; Harkness 2016). In geographical terms, then, this is an easy test for ethnic stacking theory.

The dependent variable is NAVCO 1.1's binary measure of defection, which takes a value of 1 if there are "large-scale, systematic breakdowns on the execution of orders from the target regime" (Chenoweth 2011, 34). NAVCO 1.1 measures its variable in the "peak year" of a campaign. We updated some codings in line with NAVCO 2.0 and

conducted a systematic review of the remaining codings, changing two in particular; 
details of these changes are available in the supplementary file. The dependent variable refers to mass defection and thus indicates above all the behavior of the rank and file. However, as we argue above, officers' actions can shape defection among the rank and file. Ethnic stacking theory therefore expects there to be a link between this variable and stacking in the officer corps: an officer corps with complete ethnic stacking should be able to avoid mass breakdowns in the face of uprisings from below. It is true that ethnic stacking theory also expects stacking to have effects that would not be detected by the NAVCO measure of defection. For example, ethnic stacking might help a regime survive in spite of mass defection, by reinforcing a loyal core in the face of widespread defection among out-group members (McLauchlin 2018). Such is the case in Syria. But at an aggregate level, if stacking reinforces in-group loyalty and in-group members are especially dominant in the officer corps, we contend that the likelihood of such mass defection in the first place should decline.

We rely on previous work, particularly Harkness (2016), to code our independent variables. Harkness (2016) codes whether the first post-independence government adopted an ethnic stacking policy in the armed forces and, if so, whether this was an ingroup that was already dominant (hence, complete ethnic stacking) or not (hence, incomplete ethnic stacking). For any uprising in the first year after independence, we simply used Harkness' coding of ethnic stacking in the first post-independence government. However, we reviewed all of Harkness' codes, changed one of them that did not match our findings, and added a missing code; details are in the supplementary file. We then extend Harkness' data forward in time, based on a reading of secondary material about each case. We thus produce a first code for whether a government used ethnic 
stacking or not. If it did, we produce a second code measuring whether this stacking policy matched the existing makeup of the officer corps. If a majority of officers were from in-groups, we code the case as complete ethnic stacking; if not, we code it as incomplete. We measure these variables at the outset of each case of an uprising in Africa in the NAVCO dataset since independence.

\section{Results}

Table 1. Frequency of mass defection during uprisings, by ethnic stacking

\begin{tabular}{lccc}
\hline & $\begin{array}{c}(1) \\
\text { No ethnic stacking }\end{array}$ & $\begin{array}{c}(2) \\
\text { Complete ethnic } \\
\text { stacking }\end{array}$ & $\begin{array}{c}\text { Incomplete ethnic } \\
\text { stacking }\end{array}$ \\
\hline Mass defection & $3(23 \%)$ & $7(23 \%)$ & $7(54 \%)$ \\
No mass defection & $10(77 \%)$ & $24(77 \%)$ & $6(46 \%)$ \\
\hline Total & $13(100 \%)$ & $31(100 \%)$ & $13(100 \%)$ \\
\hline Chi-square: $4.64, p<.1$ & (1) vs. (2): n.s. & \\
Statistical significance, t-tests: & (1) vs. (3): $p<.05$ & & \\
& (2) vs. (3): $p<.05$ &
\end{tabular}

In this study, we use cross-tabs in order to discuss the results in some detail, and to avoid the inference problems created by a low $\mathrm{N}$ (for logit analysis) and a binary dependent variable (for linear regression); in the supplemental file we use a regression framework that confirms our key results.

We begin with the bivariate relationship between ethnic stacking and defection in Table 1. At first glance, things do not look great for ethnic stacking as a policy. It clearly has a downside risk: consistent with $\mathrm{H} 1$, incomplete ethnic stacking comes with a higher risk of defection than either no stacking or complete stacking $(p<.05)$. But the data do not permit the conclusion that it has an upside at the aggregate level (H2): there is no difference in the incidence of mass defection between cases of complete ethnic stacking 
and no stacking at all. In further analyses, available in a supplementary file, we find that this null result cannot be explained away either by armies in which there is still a substantial presence of out-group officers despite in-group dominance; out-group presence in the rank and file rather than the officer corps; or a selection effect in which personalist regimes are likely both to employ ethnic stacking and to have relatively high defection rates (Dahl 2015).

Table 2. Frequency of mass defection during uprisings, by ethnic stacking and recent coup attempts

\begin{tabular}{|c|c|c|c|c|}
\hline & & $\begin{array}{c}(1) \\
\text { No ethnic } \\
\text { stacking }\end{array}$ & $\begin{array}{l}\text { (2) } \\
\text { Complete ethnic } \\
\text { stacking }\end{array}$ & $\begin{array}{c}\text { (3) } \\
\text { Incomplete ethnic } \\
\text { stacking }\end{array}$ \\
\hline \multirow{4}{*}{$\begin{array}{l}\text { No coup } \\
\text { attempt in last } \\
\text { ten years }\end{array}$} & Mass defection & $2(22 \%)$ & $0(0 \%)$ & $2(40 \%)$ \\
\hline & No mass defection & $7(78 \%)$ & $14(100 \%)$ & $3(60 \%)$ \\
\hline & Total & $9(100 \%)$ & $14(100 \%)$ & $5(100 \%)$ \\
\hline & $\begin{array}{l}\text { Chi-square: } 5.50, p<.1 \\
\text { Statistical significance, t-tests: }\end{array}$ & $\begin{array}{l}\text { (1) vs. (2): } p<.05 \\
\text { (1) vs. (3): } \text { n.s. } \\
\text { (2) vs. (3): } p<.05\end{array}$ & & \\
\hline \multirow{4}{*}{$\begin{array}{l}\text { Coup attempt } \\
\text { in last ten } \\
\text { years }\end{array}$} & Mass defection & $1(25 \%)$ & $7(41 \%)$ & $5(63 \%)$ \\
\hline & No mass defection & $3(75 \%)$ & $10(59 \%)$ & $3(38 \%)$ \\
\hline & Total & $4(100 \%)$ & $17(100 \%)$ & $8(100 \%)$ \\
\hline & $\begin{array}{l}\text { Chi-square: } 1.74, \text { n.s. } \\
\text { Statistical significance, t-tests: }\end{array}$ & 1 n.s. & & \\
\hline
\end{tabular}

Note: some columns do not total $100 \%$ due to rounding.

However, the null result may have to do with civil-military instability. Recall that ethnic stacking is, in theory, about creating stable expectations in an environment in which it is difficult to know officers' intentions. Recent coup attempts indicate an especially unstable, uncertain environment. Given a recent coup attempt, it is plausible that ethnic stacking would not have had the time to entrench stable expectations of behavior. In Table 2, therefore, we interact the ethnic stacking variable with a dummy 
variable indicating whether there has been a coup attempt in the ten years prior to the start of the uprising (based on Marshall and Marshall 2011). In the fourteen cases of uprisings in a regime with complete ethnic stacking and no recent history of coup attempts, mass defection never occurred. With a previous coup attempt, mass defection occurred over 40 percent of the time. In addition to the results shown in the table, this difference is statistically significant $(p<.01)$. In contrast, regimes that did not employ ethnic stacking experienced defection some of the time, even without recent coup attempts. The result hints at a conditional relationship: ethnic stacking may help prevent defection but only when combined with stable civil-military relations. With recent coups, it may not help at all.

In line with ethnic stacking theory, one obvious interpretation of this result is that it simply reflects the presence of members of marginalized ethnic out-groups, who both launch coup attempts and defect. However, we think this explanation is insufficient. As we show in the supplementary files, given a numerically dominant in-group (i.e. a case of complete ethnic stacking), defection appears to be unrelated to the significant presence or absence of marginalized out-groups.

Another possibility is that the finding reflects different institutional conditions, such as personalist regimes versus more institutionalized rule. Personalist regimes, with their unstable coalitions of competing factions, might experience both more coup attempts and greater military defection (Geddes, Wright, and Frantz 2014; Dahl 2015). They may also be less able to stably implement ethnic stacking. We test this possibility in the supplemental file, but the coups pattern we observe in Table 2 does not reappear when we break down results by regime type. In other words, it seems that the actual 
incidence of coup attempts, and not institutional features, drive defection during uprisings.

We believe that a better explanation of this result is that a history of recent coup attempts suggests above all that expectations about loyalties are not stable - a critical component of ethnic stacking. One reason would be that coup attempts undermine the expectation that in-group members are loyal to the regime. After all, it is well established that coup attempts lead to more coup attempts. A victorious coup gives an example for subsequent coup plotters. Hence, circumstances of turbulent civil-military relations may often present opportunities to fairly easily organize factions dividing in-groups. Such dynamics appear in the "coups of ethnic narrowing" that described Idi Amin's Uganda, which reduce the self-reinforcing solidarity of ethnic stacking (Horowitz 2000, 487-92). In our dataset, coup attempts do in fact sometimes reveal fractures within in-groups, as in intra-Northern coup attempts in Nigeria in 1985 and 1986 or Sudan in 1975 and 1976 (Ihonvbere 1991, 609-10; Horowitz 2000, 485). These divisions ultimately played a role in defection during uprisings against the regimes in these countries beginning in 1993 (in Nigeria) and 1985 (in Sudan). Ethnic stacking may therefore require that significant time elapse after a coup attempt before solidifying. For example, despite several coups between 1963 and 1967, Togo's ethnic stacking policy finally paid off for the Gnassingbé Éyadéma regime in the face of the pro-democracy uprising of 1990-93, as the army held firm (Morency-Laflamme 2016, ch 5).

A second mechanism relating to unstable expectations is that coup attempts may reflect changes in regime or in policy that give out-group members a limited window of opportunity to act before they are too marginalized and subordinated within the military 
hierarchy to do much. In our dataset, a history of coup attempts often indicates new regimes (some, obviously, are installed by the coup in question, like Samuel Doe in Liberia in 1980; others are able to gain power in part because of a coup-weakened incumbent, as in Milton Obote's regaining of power in Uganda in 1979-80; see Rwengabo 2013, 539; Horowitz 2000, 487-92). Coups also often correspond to new regime strategies, whether as cause or effect. For example, the marginalization of Southern officers in Sudan provoked both a coup attempt in 1977 and large-scale defection in 1983, while coup attempts in Liberia in 1985 and in Sierra Leone in 1987 prompted the further marginalization of former in-groups - whether associated with the coup attempt or not - as fearful regimes narrowed their bases of support (Horowitz 2000, 485; D. H. Johnson 2007, 62-63; Kandeh 1992, 93, 1999, 362-63; Roessler 2011, 314). Opposition campaigns in each of these countries thus occurred at a propitious moment for marginalized groups in the military.

There is thus a hint here of an upside to ethnic stacking for a regime when it comes to preventing defection during uprisings, if those regimes are able to avoid coup attempts and stabilize expectations about behavior over time. However, in order to really test the notion of convergence of expectations over time, we would need to put stacking into historical perspective, analyzing how long a stacking policy had been put in place, and - if a regime does experience coup attempts in the recent past - the other tools at its disposal to survive long enough for ethnic stacking to solidify. This is an important next step for future research.

\section{Conclusion}


This study thus provides tentative results for ethnic stacking's effects on military defection in the face of uprisings across Africa since independence. The analysis clearly demonstrates the downside risk of establishing ethnic stacking in the face of another group that is numerically dominant in the officer corps. However, evidence in support of the upside of ethnic stacking for a regime is more limited. There is no overall evidence for a lower incidence of mass defection when a regime makes an in-group dominant, than when it does not employ ethnic stacking at all. An intriguing pattern that emerges, however, is that stacking does seem to prevent defection in regimes with no recent coup history. It is possible that this shows that ethnic stacking requires a period of military stability to solidify, although historical analysis would be important to verify this.

The most important next step for large- $\mathrm{N}$ analyses of stacking and defection is to gather time-variant data on stacking policies, not just observing them at key moments like regime crises. This would permit a fuller analysis both of the selection process of ethnic stacking and of the historical character of its implementation. Disaggregated data breaking down defection behavior by members of different ethnic groups would permit a more detailed test of the key hypotheses of ethnic stacking theory.

\section{Bibliography}

Albrecht, Holger, and Dorothy Ohl. 2016. "Exit, Resistance, Loyalty: Military Behavior during Unrest in Authoritarian Regimes." Perspectives on Politics 14 (01): 38-52. https://doi.org/10.1017/S1537592715003217.

Allen, Chris. 1992. "Restructuring an Authoritarian State: 'Democratic Renewal' in Benin." Review of African Political Economy 19 (54): 42-58. https://doi.org/10.1080/03056249208703952.

Barany, Zoltan D. 2016. How Armies Respond to Revolutions and Why. Princeton: Princeton University Press. 
Bou Nassif, Hicham. 2015. "'Second-Class': The Grievances of Sunni Officers in the Syrian Armed Forces." Journal of Strategic Studies 38 (5): 626-49. https://doi.org/10.1080/01402390.2015.1053604.

Bratton, M., and N. van de Walle. 1994. "Neopatrimonial Regimes and Political Transitions in Africa." World Politics 46 (04): 453-89.

Brooks, Risa. 1998. Political-Military Relations and the Stability of Arab Regimes. Adelphi Paper 324. London: International Institute for Strategic Studies. . 2019. "Integrating the Civil-Military Relations Subfield." Annual Review of Political Science 22 (1). https://doi.org/10.1146/annurev-polisci-060518-025407.

Casper, Brett Allen, and Scott A. Tyson. 2014. "Popular Protest and Elite Coordination in a Coup d'état." The Journal of Politics 76 (2): 548-64. https://doi.org/10.1017/S0022381613001485.

Chandra, Kanchan. 2004. Why Ethnic Parties Succeed: Patronage and Ethnic Head Counts in India. Cambridge: Cambridge University Press. . 2006. "What Is Ethnic Identity and Does It Matter?" Annual Review of Political Science 9 (June): 397-424. https://doi.org/10.1146/annurev.polisci.9.062404.170715.

Chandra, Kanchan, and Steven I. Wilkinson. 2008. "Measuring the Effect of 'Ethnicity.", Comparative Political Studies 41 (4-5): 515-63.

Chenoweth, Erica. 2011. "Online Methdological Appendix Accompanying 'Why Civil Resistance Works."' Wesleyan University.

Chenoweth, Erica, and Maria J. Stephan. 2011. Why Civil Resistance Works: The Strategic Logic of Nonviolent Conflict. New York: Columbia University Press.

Chorley, Katharine. 1943. Armies and the Art of Revolution. Boston: Beacon Press.

Dahl, Marianne. 2015. "The Unintended Consequences of Coup-Proofing: Authoritarian Regimes and Military Defection.” Unpublished manuscript. Oslo.

De Bruin, Erica. 2018. "Preventing Coups d'état: How Counterbalancing Works." Journal of Conflict Resolution 62 (7): 1433-58. https://doi.org/10.1177/0022002717692652.

Emizet, Kisangani N. F. 2000. "Explaining the Rise and Fall of Military Regimes: CivilMilitary Relations in the Congo.” Armed Forces \& Society 26 (2): 203-27. https://doi.org/10.1177/0095327X0002600203.

Enloe, Cynthia H. 1980. Ethnic Soldiers: State Security in Divided Societies. Athens, GA: University of Georgia Press.

Fearon, James D., and David D. Laitin. 2003. "Ethnicity, Insurgency, and Civil War." American Political Science Review 97 (01): 75-90.

Geddes, Barbara, Joseph Wright, and Erica Frantz. 2014. "Autocratic Breakdown and Regime Transitions: A New Data Set.” Perspectives on Politics 12 (02): 313-31. https://doi.org/10.1017/S1537592714000851.

Harkness, Kristen A. 2016. "The Ethnic Army and the State: Explaining Coup Traps and the Difficulties of Democratization in Africa." Journal of Conflict Resolution 60 (4): 587-616. https://doi.org/10.1177/0022002714545332.

Horowitz, Donald. 2000. Ethnic Groups in Conflict. 2nd ed. Berkeley and Los Angeles: University of California Press. 
Ihonvbere, Julius O. 1991. "A Critical Evaluation of the Failed 1990 Coup in Nigeria." The Journal of Modern African Studies 29 (04): 601. https://doi.org/10.1017/S0022278X00005681.

Johnson, Douglas H. 2007. The Root Causes of Sudan's Civil Wars. African Issues. Oxford: James Currey.

Kandeh, Jimmy D. 1992. "Politicization of Ethnic Identities in Sierra Leone." African Studies Review 35 (1): 81. https://doi.org/10.2307/524446. . 1999. "Ransoming the State: Elite Origins of Subaltern Terror in Sierra Leone." Review of African Political Economy 26 (81): 349-66. https://doi.org/10.1080/03056249908704398.

Koehler, Kevin. 2017. "Political Militaries in Popular Uprisings: A Comparative Perspective on the Arab Spring." International Political Science Review 38 (3): 363-77.

Koehler, Kevin, Dorothy Ohl, and Holger Albrecht. 2016. "From Disaffection to Desertion: How Networks Facilitate Military Insubordination in Civil Conflict." Comparative Politics 48 (4): 439-57.

Kuran, Timur. 1991. "Now Out of Never: The Element of Surprise in the East European Revolution of 1989." World Politics 44 (1): 7-48.

La Parra-Pérez, Álvaro. 2014. "The Spanish Civil War: A New Institutional Interpretation of the Social Order and Military Factions during the Second Republic (1931-1939)." PhD dissertation, College Park, MD: University of Maryland.

Makara, Michael. 2013. "Coup-Proofing, Military Defection, and the Arab Spring." Democracy and Security 9 (4): 334-59.

Marshall, Monty G., and Donna Ramsey Marshall. 2011. "Coup d'État Events, 19462010." Center for Systemic Peace.

McLauchlin, Theodore. 2010. "Loyalty Strategies and Military Defection in Rebellion." Comparative Politics 42 (3): 333-50.

- 2018. "The Loyalty Trap: Regime Ethnic Exclusion, Commitment Problems, and Civil War Duration in Syria and Beyond." Security Studies 27 (2): 296-317. https://doi.org/10.1080/09636412.2017.1386938.

Morency-Laflamme, Julien. 2016. "Regime Crises in Africa: A Study of the Armed Forces' Behaviour." PhD dissertation, Montreal: Université de Montréal.

— 2018. "A Question of Trust: Military Defection during Regime Crises in Benin and Togo." Democratization 25 (3): 464-80. https://doi.org/10.1080/13510347.2017.1375474.

Nepstad, Sharon Erickson. 2013. "Mutiny and Nonviolence in the Arab Spring: Exploring Military Defections and Loyalty in Egypt, Bahrain, and Syria." Journal of Peace Research 50 (3): 337-49.

Powell, Jonathan M. 2012. "Determinants of the Attempting and Outcome of Coups d'etat." Journal of Conflict Resolution 56 (6): 1017-40. https://doi.org/10.1177/0022002712445732.

Quinlivan, James T. 1999. "Coup-Proofing: Its Practice and Consequences in the Middle East." International Security 24 (2): 131-65.

Roessler, Philip G. 2011. "The Enemy Within: Personal Rule, Coups, and Civil Wars in Africa." World Politics 63 (2): 300-346. 
Russell, D.E.H. 1974. Rebellion, Revolution, and Armed Force: A Comparative Study of Fifteen Countries with Special Emphasis on Cuba and South Africa. New York: Academic Press.

Rwengabo, Sebastian. 2013. "Regime Stability in Post-1986 Uganda: Counting the Benefits of Coup-Proofing." Armed Forces \& Society 39 (3): 531-59. https://doi.org/10.1177/0095327X12437690.

Singh, Naunihal. 2014. Seizing Power: The Strategic Logic of Military Coups. Baltimore, MD: Johns Hopkins University Press.

Sudduth, Jun Koga. 2017a. "Strategic Logic of Elite Purges in Dictatorships." Comparative Political Studies 50 (13): 1768-1801.

—. 2017b. "Coup Risk, Coup-Proofing and Leader Survival." Journal of Peace Research 54 (1): 3-15. https://doi.org/10.1177/0022343316676885.

Talmadge, Caitlin. 2015. The Dictator's Army: Battlefield Effectiveness in Authoritarian Regimes. Cornell Studies in Security Affairs. Ithaca: Cornell University Press. Wucherpfennig, Julian, Nils W. Metternich, Lars-Erik Cederman, and Kristian Skrede Gleditsch. 2012. "Ethnicity, the State, and the Duration of Civil War." World Politics 64 (1): 79-115. 